\title{
Cytotoxicity and Anti-Inflammatory Activity of Tamarillo (Solanum betaceum Cav.) Peel Extract in Lipopolysaccharide Stimulated RAW 264.7 Cells
}

\section{Novelya Li, Wilvia Li}

Faculty of Dentistry Universitas Prima Indonesia, Medan, Sumatera Utara, Indonesia Email: novelya@unprimdn.ac.id

\begin{abstract}
Abstrak: Obat anti inflamasi sering diresepkan dalam bidang kedokteran gigi. Umumnya obatobat ini memiliki efek samping beragam, dari yang ringan hingga parah seperti perdarahan lambung. Oleh karena itu, bahan anti inflamasi yang alami dan lebih aman diperlukan sebagai alternatif. Solanum betaceum Cav., dikenal sebagai terong Belanda, merupakan buah eksotik yang dapat juga dipergunakan sebagai bahan obat. Limbah buah seperti kulit dan biji biasanya tidak dikonsumsi. Beberapa penelitian menunjukkan bahwa limbah dari berbagai jenis buah mengandung senyawa bioaktif yang bermanfaat. Penelitian ini bertujuan untuk mengetahui sitotoksistas dan kemampuan anti-inflamasi dari ekstrak kulit terong Belanda terhadap makrofag lini RAW 264.7 yang diinduksi oleh lipopolisakarida (LPS). Sitotoksistas diuji untuk menentukan konsentrasi yang aman dengan menggunakan metode MTS. Aktivitas anti-inflamasi dinilai dengan membandingkan kadar PGE-2, TNF- $\alpha$, dan IL-1 $\beta$ pada sel RAW 264.7 yang distimulasi LPS antara kelompok yang diberikan ekstrak dan yang tidak diberikan ekstrak menggunakan metode ELISA. Hasil penelitian mendapatkan bahwa ekstrak kulit terong Belanda dapat menekan produksi PGE-2, TNF- $\alpha$, dan IL-1 $\beta$ pada sel RAW 264.7 yang diinduksi dengan LPS. Simpulan penelitian ini ialah ekstrak kulit Solanum betaceum Cav memiliki kemampuan antiinflamasi melalui penekanan produksi PGE-2, TNF- $\alpha$, dan IL-1 $\beta$ pada sel RAW 264.7 yang diinduksi LPS. Kata kunci: ekstrak kulit Solanum betaceum Cav. (terong Belanda), sitotoksistas, antiinflamasi
\end{abstract}

\begin{abstract}
Anti-inflammatory agents are commonly prescribed in dentistry. Most of them have side effects varying from mild to severe such as gastric bleeding. Therefore, a safer and natural anti-inflammatory agent is needed as an alternative. Solanum betaceum Cav., known as tamarillo, is one of exotic fruits used in traditional medicines. The fruit wastes such as peels and seeds, are usually unconsumed. However, many investigators have reported that wastes from numerous fruits had potent bioactive compounds. This study was aimed to assess the cytotoxicity and antiinflammatory activities of tamarillo peel extract (TPE) in lipopolysaccharide (LPS) stimulated RAW 264.7 macrophage cell line. The cytotoxicity of TPE was performed to determine the nontoxic concentration by using MTS method. The inflammatory markers measured in this study were PGE-2, TNF- $\alpha$, and IL-1 $\beta$. Their concentrations were measured by using ELISA based assay. The anti-inflammatory activity was determined by comparing the reduction of the inflammatory mediators between the LPS stimulated RAW 264.7 cells treated with TPE and the non-treated group. This study revealed that TPE could reduce the production of PGE-2, TNF- $\alpha$, and IL- $1 \beta$ in LPS stimulated RAW 264.7 cells. In conclusion, tamarillo peel extract possess an antiinflammatory effect by reducing the production of PGE- 2 , TNF- $\alpha$, and IL- $1 \beta$ in LPS stimulated RAW 264.7 cells.
\end{abstract}

Keywords: Solanum betaceum Cav. (tamarillo) peel extract, cytotoxicity, anti-inflammatory

\section{INTRODUCTION}

The utilization of medicinal plants for disease management has played a central role since ancient times. ${ }^{1,2}$ Dentistry also has started to utilize medicinal plants to relieve oral problems. ${ }^{3}$ Thus, the demand for medi- 
cinal plants is also increasing nowadays. ${ }^{1,4}$ This might be due to the inexpensive price of herbal medicines compared to Western medicines. ${ }^{1}$ Moreover, the problems due to adverse drug reactions of some Western medicines are very prominent. ${ }^{4}$ On the other hand, medicinal plants are considered to be safe and effective. ${ }^{5}$ As the demand of medicinal plants is increasing, pharmacologists become more aware to study the safety, efficacy, and toxicity of the medicinal plant. $^{6}$ One of its efficacy is the anti-inflammatory potential of natural compounds. ${ }^{7}$ Medicinal plants possess numerous of active phytochemical compounds with various biological activities. Scientists are highly interested in studying plants in order to isolate novel herbal drugs to substitute synthetic drugs. ${ }^{8}$ Therefore, the initial step to evaluate the cytotoxicity of plant extracts is important to promote successful development of pharmaceutical preparation of minimal to no toxic effect herbal drugs to the host. ${ }^{9}$

Inflammation is a vital defense mechanism of human body against harmful stimuli, such as pathogens, damaged cells, toxic compounds, or irradiation, removes harmful stimuli, and initiates healing. ${ }^{10}$ In the past, inflammation was known as part of healing process. But nowadays, inflammation is seen as an unwanted response which is harmful to the host. ${ }^{11}$ During inflammatory responses, cellular and molecular processes and their interactions minimize the injury or infection. However, uncontrolled inflammation may turn to chronic state, contributing to various chronic inflammatory diseases. Several proinflammatory cytokines are involved in inflammatory process, such as interleukin- $1 \beta$ (IL-1 $\beta$ ), tumor necrosis factor- $\alpha$ (TNF- $\alpha$ ), and interleukin-6 (IL-6). ${ }^{10}$ IL- $1 \beta$ is released by monocytes, macrophages, fibroblasts, and endothelial cells during inflammation, invasion, infection and cell injury. ${ }^{12}$ IL- $1 \beta$ upregulates other pro-nociceptive mediators, thus facilitates synaptic activity and pain transmission, and contribute to the development of chronic pain. TNF- $\alpha$ plays a wellknown role in some pain models and acts on several different signaling pathways through two cell surface receptors. ${ }^{13}$ On the other hand, prostaglandin (PG) production, especially abundantly detecting PGE-2, can also exacerbate inflammatory response. PGE-2 induces acute inflammatory reaction by activating mast cells via EP3 receptor. PGE2 also induces chronic inflammatory reaction by differentiation of Th-1 (T helper-1), proliferation of Th-12, and production of IL-22 by Th-22 via EP2 and EP4 pathways. ${ }^{14}$

The most commonly prescribed medications for pain and inflammation, the nonsteroidal anti-inflammatory drugs (NSAIDs), are highly effective, but are also known for multiple adverse effects such as gastrointestinal bleeding, cardiovascular effects, and nephrotocicity. ${ }^{15}$ Due to the side effects of NSAIDs, high interests are found toward herbal remedies to reduce pain and inflamemation. ${ }^{16}$ Many of these herbal materials possess anti-inflammatory effect, can stop bleeding, and act in similar pathway as NSAIDs, which are necessary in dental treatment. ${ }^{3,16}$ The natural compound that is commonly identified in natural herbs is flavonoid. Flavonoids belong to an important class of natural compounds which possesses the anti-inflammatory, anti-oxidative, antimutagenic and anti-carcinogenic properties. Flavonoids are widely found in fruits, vegetables, and certain beverages. ${ }^{17}$ An example of the fruits is tamarillo (Solanum betaceum Cav.), an exotic nutritious fruit which is easily found, processed, and consumed. Both tamarillo peel and flesh contains several phytochemicals including flavonoids, anthocyanins, and carotenoids. ${ }^{18,19}$ Therefore, the aim of this study was to evaluate the cytotoxic and anti-inflammatory effects of various concentrations of tamarillo peel extracts (TPE) in LPS stimulated RAW 264.7 cell line. Based on the literatures given, we hypothesized that TPE in various concentrations were able to reduce the production of PGE-2, IL- $1 \beta$, and TNF- $\alpha$ as pro-inflammatory cytokines.

\section{METHODS}

This was an experimental study by posttest only with control group design that compared the cytotoxicity of various concentrations of tamarillo peel extracts (TPE) and 
its effect toward the concentrations of PGE2 , IL- $1 \beta$, and TNF- $\alpha$. Figure $1 \mathrm{~A}$ and $\mathrm{B}$ showed the fresh tamarillo fruits as well as dried tamarillo fruits.

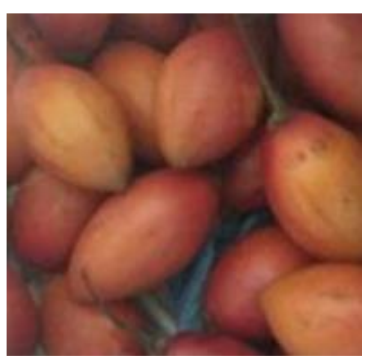

A

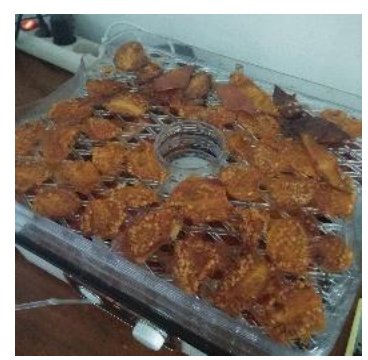

B
Figure 1. A) Fresh tamarillo fruits; B) Dried tamarillo.fruits

Tamarillo peel extracts (TPE) was obtained by using maceration technique with $70 \%$ ethanol.

The macrophage cell line RAW 264.7 (ATCC TIB-71) culture was done on Dulbecco's modified eagle's medium (DMEM, Gibco 11995065) added with 10\% of fetal bovine serum (FBS, Biowest $\mathrm{S} 181 \mathrm{H}$ ), and $1 \%$ of antibiotic and antimycotic (ABAM, Gibco 1772653). The culture was incubated at $37^{\circ} \mathrm{C}$ with $5 \%$ of $\mathrm{CO} 2$ until the $70-80 \%$ of the cells were confluent. The culture was then washed and harvested. ${ }^{20-22}$

Cytotoxicity test was measured by MTS assay based on the conversion of yellow tetrazolium salt to form a purple formazan product. MTS (Abcam, ab197010) was used. Cells were seeded in a 96-well plate $\left(5 \times 10^{3}\right.$ cell/well) then were incubated for 24 hours at $37^{\circ} \mathrm{C}$ with $5 \% \mathrm{CO}_{2}$. After 24 hours, each well was supplemented with $180 \mu \mathrm{l}$ new culture medium along with $20 \mu \mathrm{l}$ of the TPE in various concentration $(12.5 \mu \mathrm{g} / \mathrm{ml}, 25 \mu \mathrm{g} / \mathrm{ml}$, $50 \mu \mathrm{g} / \mathrm{ml}$, and $100 \mu \mathrm{g} / \mathrm{ml})$. The cells were then incubated for another 24 hours at $37^{\circ} \mathrm{C}$ with $5 \% \mathrm{CO}_{2}$. After 24 hours, $20 \mu \mathrm{l}$ of MTS were added on each well then be incubated for 3 hours at $37^{\circ} \mathrm{C}$ with $5 \% \mathrm{CO}_{2}$. The absorbance was measured by using spectrophotometry at $490 \mathrm{~nm} .^{20-22}$

The pro-inflammatory activation of RAW 264.7 cell process was, as follows: cells were plated in a 6-well plate (1000 cells/plate) then were incubated for 24 hours at $37^{\circ} \mathrm{C}$ with $5 \% \mathrm{CO}_{2}$. After 24 hours, the culture medium was discharged, the plate was added with $1600 \mu \mathrm{l}$ of new culture medium along with $200 \mu \mathrm{l}$ TPE $(12.5$ and $50 \mu \mathrm{g} / \mathrm{ml})$ then was incubated for $1-2$ hours at $37^{\circ} \mathrm{C}$ with $5 \% \mathrm{CO}_{2}$. Further, $200 \mu \mathrm{l}$ of $1 \mu \mathrm{g} / \mathrm{ml}$ LPS (Sigma Aldrich, L2880) was added into each well and the plate was incubated for 24 hours at $37^{\circ} \mathrm{C}$ with $5 \% \quad \mathrm{CO}_{2}$. The conditioned medium was collected in a small tube and centrifuged at $2000 \mathrm{xg}$ for 10 minutes. The supernatant was collected and stored at $-80^{\circ} \mathrm{C}$ for quantification of PGE-2, IL-1 $\beta$, and TNF$\alpha$ concentration. ${ }^{20-22}$

In quantification of PGE-2, IL-1 $\beta$, and TNF- $\alpha$ concentrations, the process was as follow: PGE-2 concentration was measured using ELISA PGE-2 mouse kit from Elabscience (E-EL-M0052). An amount of $100 \mu 1$ of standard solution was added twice into the wells, then the wells were sealed and incubated for 90 minutes at $37^{\circ} \mathrm{C}$. The solution was discharged, then $100 \mu \mathrm{l}$ of biotinylated detection $\mathrm{Ab}$ solution was added to each well, sealed, and incubated for 1 hour at $37^{\circ} \mathrm{C}$. After one hour, the solution was washed away using wash buffer repeated for three times. $100 \mu \mathrm{l}$ of HRP conjugate was then added to each plate and covered an incubated for 30 minutes at $37^{\circ} \mathrm{C}$. The plate was then washed for five times and $90 \mu \mathrm{l}$ of reagent was added to each well followed by incubation for $15-30$ minutes at $37^{\circ} \mathrm{C}$. After incubation, $50 \mu \mathrm{l}$ of stop solution was added to each well then optical density was measured at $450 \mathrm{~nm}$ using spectrophotometer. The similar procedure was repeated for TNF- $\alpha$ and IL- $1 \beta$ using ELISA TNF- $\alpha$ mouse kit (Elabscience, E-EL-M0049) and ELISA IL$1 \beta$ mouse kit (Elabscience, E-EL-M0037). ${ }^{20-}$ ${ }^{22}$ All experiments done in this study were performed in triplicate for each group.

Statistical analysis was conducted by using SPSS software. All data were presented as mean \pm deviation standard. Any significant differences between the groups presented in this study were determined by ANOVA followed by Tukey HSD post hoc test. 


\section{RESULTS}

The cytotoxic effects of TPE were evaluated against raw 263.7 cells using MTS assay. The concentrations tested were 12.5 $\mu \mathrm{g} / \mathrm{ml}, 25 \mu \mathrm{g} / \mathrm{ml}, 50 \mu \mathrm{g} / \mathrm{ml}$, and $100 \mu \mathrm{g} / \mathrm{ml}$. The cytotoxic test showed that only $72.77 \%$ of cells survived after stimulated with $100 \mu \mathrm{g} / \mathrm{ml}$ of TPE. Whereas, the stimulation of $12.5 \mu \mathrm{g} / \mathrm{ml}, 25 \mu \mathrm{g} / \mathrm{ml}$, and $50 \mu \mathrm{g} / \mathrm{ml}$ showed high cell viabilities which were $108.96 \%, 104.44 \%$, and $99.26 \%$ respectively. Based on ANOVA Tukey post hoc test, the viability of RAW 264.7 cells induced by 100 $\mu \mathrm{g} / \mathrm{ml}$ of TPE was statistically lower compared to the viabilities of RAW 264.7 cells induced by $12.5 \mu \mathrm{g} / \mathrm{ml}, 25 \mu \mathrm{g} / \mathrm{ml}$, and 50 $\mu \mathrm{g} / \mathrm{ml}$ of TPE. Whereas, the viabilities of RAW 264.7 cells induced by $12.5 \mu \mathrm{g} / \mathrm{ml}, 25$ $\mu \mathrm{g} / \mathrm{ml}$ and $50 \mu \mathrm{g} / \mathrm{ml}$ TPE were not statistically significant (Figure 2).

\section{DISCUSSION}

Viability cell assays are used to measure cell proliferation, testing for its cytotoxic effect. ${ }^{23}$ This viability test is important in pharmacology prior to clinical use of any drug or chemical compound..$^{22-24}$ In this study, the viability cell assay was carried out by using MTS assay. Non toxicity was recorded by $80 \%$ or more viable cells. ${ }^{24}$ Based on this study, the concentrations of TPE ranged between $12.5-50 \mu \mathrm{g} / \mathrm{ml}$ were non-toxic, and cells' viabilities were more than $80 \%$. These groups were considered to be safe for living cells. However, group of $100 \mu \mathrm{g} / \mathrm{ml}$ of TPE showed lower viability which was less than $80 \%$ (72.77\%), therefore, it was considered as low toxicity. ${ }^{24}$

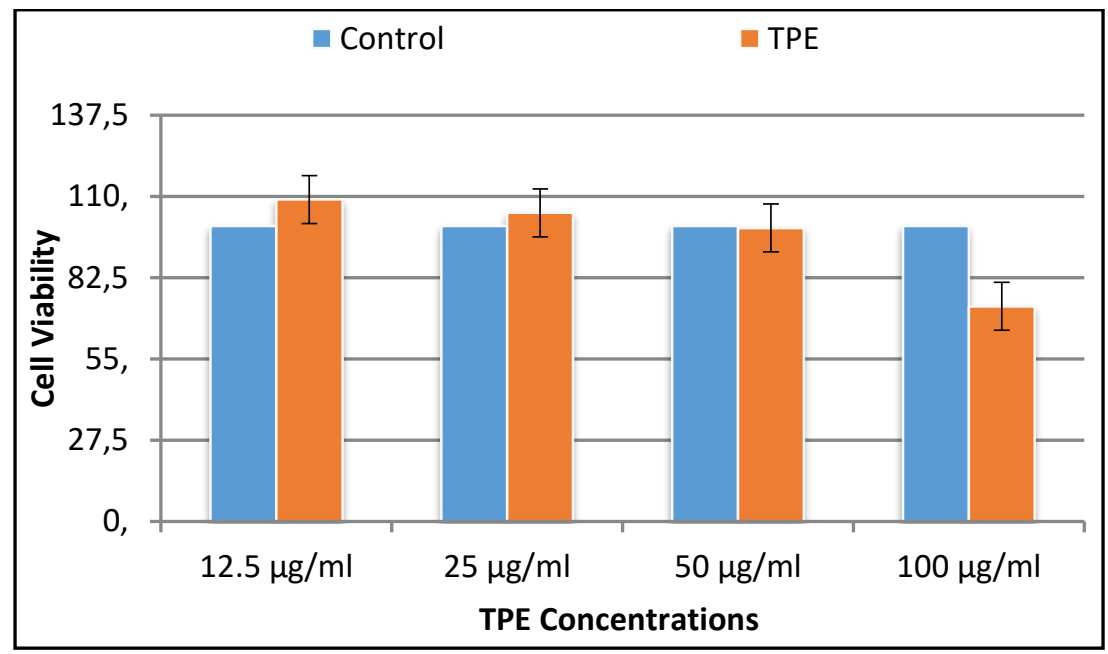

Figure 2. Viability of RAW 264.7 cells induced by TPE of various concentrations

Table 1. PGE-2, IL-1 $\beta$, and TNF- $\alpha$ concentration on RAW 264.7 cell line after induction with TPE

\begin{tabular}{cccc}
\hline Samples & $\begin{array}{c}\text { PGE-2 Concentration } \\
(\mathrm{pg} / \mathrm{mL}) \pm \mathrm{SD}\end{array}$ & $\begin{array}{c}\text { IL1- } \beta \text { Concentration } \\
(\mathrm{pg} / \mathrm{mL}) \pm \mathrm{SD}\end{array}$ & $\begin{array}{c}\text { TNF- } \alpha \text { Concentration } \\
(\mathrm{pg} / \mathrm{mL}) \pm \mathrm{SD}\end{array}$ \\
\hline (+) Control & $866,44 \pm 39,02^{\mathrm{e}}$ & $437,06 \pm 25,72^{\mathrm{d}}$ & $582,63 \pm 25,23^{\mathrm{c}}$ \\
(-) Control & $404,51 \pm 10,31^{\mathrm{a}}$ & $139,04 \pm 7,91^{\mathrm{a}}$ & $242,17 \pm 18,95^{\mathrm{a}}$ \\
$12,5 \mu \mathrm{g} / \mathrm{ml} \mathrm{TPE}$ & $747,63 \pm 25,32^{\mathrm{d}}$ & $347,55 \pm 23,67^{\mathrm{c}}$ & $438,81 \pm 33,53^{\mathrm{b}}$ \\
$75 \mu \mathrm{g} / \mathrm{ml}$ TPE & $501,12 \pm 32,56^{\mathrm{b}}$ & $176,15 \pm 15,84^{\mathrm{a}}$ & $276,48 \pm 43,82^{\mathrm{a}}$ \\
\hline
\end{tabular}

Note: All data were presented as mean \pm SD. Different lowercase letters in the same column were statistically significant at $\mathrm{p}<0.05$ (Tukey HSD post hoc test). 
The anti-inflammatory potential of TPE extracts in this study was observed through the inhibitory activity against inflammatory markers such as PGE-2, IL-1 $\beta$, and TNF- $\alpha$ on LPS induced macrophage cell line (RAW 264.7). PGE-2 was the most abundantly produced prostaglandins in human body. During inflammation process, PGE-2 involves in almost all inflammatory signs, such as redness, swelling, and pain. ${ }^{25}$ The reduction of PGE-2 production will reduce the inflamemation and enhance healing process. ${ }^{26}$ IL1- $\beta$ acts in homeostatic functions. However, IL1- $\beta$ overproduction occurs in pathophysiological changes. IL1- $\beta$ can be released by immune cells and non-immune cells and plays a role in inflammation and pain by Caspase- 1 via the inflammasomes. On the other hand, IL1- $\beta$ can lead to the release and/or activation of nociceptive molecules such as prostaglandins, IL-6, substance P, and MMP9. ${ }^{14}$ TNF- $\alpha$ is a pro-inflammatory cytokine that is simultaneously produced with interleukins which modulates pro-inflammatory signals by coordinating vascular and cellular alterations in the immune system. ${ }^{27}$

This study showed that application of $12.5 \mu \mathrm{g} / \mathrm{ml}$ and $75 \mu \mathrm{g} / \mathrm{ml}$ of TPE significantly decreased the production of PGE-2, IL1- $\beta$, and TNF- $\alpha$ compared to the LPS stimulated group. In addition, the reductions of IL1- $\beta$ and TNF- $\alpha$ production after induction with 75 $\mu \mathrm{g} / \mathrm{ml}$ of TPE were similar to the nonstimulated group. Based on this study, 12.5 $\mu \mathrm{g} / \mathrm{ml}$ and $75 \mu \mathrm{g} / \mathrm{ml}$ of TPE may be a potential anti-inflammatory agent which did not possess toxic effect toward RAW 264.7 macrophage cell line. These results were consistent with the previous research that supplementation of Cyphomandra betacea (tamarillo) extracts successfully decreased the production of inflammatory biomarkers. ${ }^{28}$ According to Kadir et al, ${ }^{28}$ Cyphomandra betacea (tamarillo) supplement given to obese induced rats were able to reduce the concentration of TNF- $\alpha$ and IL- 6 in blood.

This anti-inflammatory potential of TPE is caused by the content of phytochemical compounds such as flavonoids, tannins, saponin, and alkaloids. ${ }^{29}$ The flavonoids found in TPE are flavons, flavonols, and isoflavons. ${ }^{19}$ Many researches have showed that bioactive compounds found in plants have pharmacologic effect towards diseases including inflammatory related diseases. ${ }^{30}$ Flavonoids are able to inhibit several enzymes including cyclooxygenase, ${ }^{31}$ phospolipase A2 and lipooxygenase, thus reduce the concentrations of prostanoids and leukotrines. ${ }^{32}$ Flavonoids was believed to be able to inhibit neutrophil degranulation. ${ }^{33}$

Other bioactive compounds found in TPE is flavons. Flavons act as an antiinflammatory agent through modulation of pro-inflammatory gene expression such as cyclooxigenase-2 (COX-2), nitric oxide synthase (NOS), and several cytokines. ${ }^{32}$ Cyclooxygenases and lipooxygenases play some important roles during inflammatory process. These enzymes are involved in arachidonic acid formation which is the initial process of inflammation process. This activity releases cytokines, thus, the inhibition of these enzymes will reduce the production of inflammatory metabolites. ${ }^{33}$

Tannins possess an anti-inflammatory activity through inhibition of inflammatory mediator expression, such as several types of cytokines, inducible NOS, and COX-2. ${ }^{34}$ Tannin inhibits the expression of COX-2 through NF-kB and MAPK pathways, thus the pro-inflammatory gene transcriptions such as TNF- $\alpha$, IL-6, dan IL- $1 \beta$ are also reduced. Inhibition of COX-2 expression also reduces prostaglandin production. ${ }^{35}$

\section{CONCLUSION}

TPE in lower concentration $(12.5 \mu \mathrm{g} / \mathrm{ml}$, $25 \mu \mathrm{g} / \mathrm{ml}$, and $50 \mu \mathrm{g} / \mathrm{ml}$ ) shows no toxic effect towards macrophage cell lines and has anti-inflammatory potential proven by its ability to reduce the production of proinflammatory mediators including PGE-2, IL- $1 \beta$, and TNF- $\alpha$ on LPS induced macrophage cell lines.

\section{Source of Funding}

This study was funded by Direktorat Riset dan Pengabdian Masyarakat, Direktorat Jenderal Penguatan Riset dan Pengembangan, Kementerian Riset, Teknologi dan Pendidikan Tinggi Republik Indonesia. 


\section{Acknowledgement}

We would like to thank Direktorat Riset dan Pengabdian Masyarakat, Direktorat Jenderal Penguatan Riset dan Pengembangan, Kementerian Riset, Teknologi dan Pendidikan Tinggi Republik Indonesia for the financial support for this study. We are also thankful to Wahyu Widowati from Biomolecular and Biomedical Research Center, Aretha Medika Utama, Bandung for his valuable support and assistance.

\section{Conflict of Interest}

The authors declare no conflict of interests in this study.

\section{REFERENCES}

1. Schippmann U, Leaman DJ, Cunningham AB. Impact of cultivation and gathering of medicinal plants on biodiversity: global trends and issues. FAO. 2002:1-21. Available from: http://www.fao.org/ 3/aa010e/AA010e00.htm.

2. Zhang JH, Onakpoya IJ, Posadzki P, Eddouks M. The safety of herbal medicine: from prejudice to evidence. Evid Based Complement Alternat Med. 2015;2015:13.

3. Martinez CC, Gomez MD, Oh MS. Use of traditional herbal medicine as an alternative in dental treatment in Mexican dentistry: a review. Pharm Biol. 2017; 55(1):1992-8.

4. Chen SL, Yu H, Luo HM, Wu Q, Li CF, Steinmetz A. Conservation and sustainable use of medicinal plants: problems, progress, and prospects. Chin Med. 2016; 11:1-10.

5. Nasri H, Shirzad H. Toxicity and safety of medicinal plants. J Herb Med Plarmacol. 2013;2(2):21-2.

6. Ghana Medical Journal. Herbal Medicine Research. Ghana Med J. 2013;47(3):100.

7. Patel VR, Patel PP, Kujal SS. Antioxidant activity of some selected medicinal plants in Western region of India. Adv Biol Res. 2010;4(1):23-6.

8. Nemudzivhadi V, Masoko P. In vitro assessment of cytotoxicity, antioxidant, and antiinflammatory activities of Ricinus communis (Euphorbiaceae) leaf extracts. Evid Based Complement Alternat Med. 2014;2014:1-8.

9. McGaw LJ, Elgorashi EE, Eloff JN. Cytotoxicity of African medicinal plants against normal animal and human Cells. In: Kuete V, editor. Toxicological Survey of African Medicinal Plants. Elsevier, 2014; p. 181-233.

10. Chen L, Deng H, Cui H, Fang J, Zuo Z, Deng J, et al. Inflammatory responses and inflammation associated diseases in organs. Oncotarget. 2017;9(6):7204-18.

11. Punchard NA., Whelan CJ., Adcock I. The Journal of Inflammation. J Inflamm (Lond). 2004;1:1. Doi: https://doi.org/ 10.1186/ 1476-9255-1-1

12. Zhang JM, An J. Cytokines, inflammation, and pain. Int Anesthesiol Clin. 2007;45(2): 27-37.

13. Ren K, Torres R. Role of interleukin-1beta during pain and inflammation. Brain Res Rev. 2009;60(1):57-64.

14. Tsuge K, Inazumi T, Shimamoto A, Sugimoto Y. Molecular mechanisms underlying prostaglandin E2-exacerbated inflame mation and immune diseases. Int Immunol. 2019;31(9): 597-606.

15. Wongrakpanich S, Wongrakpanich A, Melhado K, Rangaswami J. A comprehensive review of non-steroidal anti-inflammatory drug use in the elderly. Aging Dis. 2018;9(1):143-50.

16. Maroon JC, Bost JW, Maroon A. Natural antiinflammatory agents for pain relief. Surg Neurol Int. 2010;1:80.

17. Panche AN, Diwan AD, Chandra SR. Flavonoids: an overview. J Nutr Sci. 2016;5:e47.

18. Skinner SJ, Hunter D, Cho S, Skinner M. The potential health benefits of the subtropical fruits kiwifruit, feijoa and tamarillo. In: Skinner M, Hunter D, editors. Bioactives in Fruit: Health Benefits and Functional Foods. Chichester: Wiley Blackwell, 2013; p. 186-87.

19. Widayanti NP, Puspawati NM, Suarsana IN, Asih IARA, Rita WS. Aktivitas antioksidan fraksi n-butanol ekstrak kulit terong Belanda (Solanum betaceum Cav.) secara in vitro dan identifikasi senyawa golongan flavonoidnya. Cakra Kimia Indonesian E-journal of Applied Chemistry. 2016; 4(1):30-7.

20. Widowati W, Darsono L, Suherman J, Fauziah N, Maesaroh M, Putu EP. Antiinflammatory effect of mangosteen (Garcinia mangostana L.) peel extract and its compounds in LPS-induced RAW 
264.7 cells. Nat Prod Sci. 2016;22(3):1-7.

21. Laksmitawati DR, Widyastuti A, Nadia K, Afifah E, Rihibiha DD, Nufus $\mathrm{H}$, et al. Anti-inflammatory effects of Anredera cordifolia and Piper crocatum extracs on lipopolysaccharide stimulated macrophage cell line. Bangladesh J Pharmacol. 2017; 12:35-40.

22. Dewi K, Widyarto B, Erawijantari PP, Widowati W. In vitro study of Myristica fragrans seed (Nutmeg) ethanolic extract and quercetin compound as antiinflammatory agent. International Journal of Research in Medical Sciences. 2017;3(9):2303-10.

23. Riss TL, Moravec RA, Niles AL, Duellman S, Benik HA, Worzella TJ, et al. Cell viability assays. 2013 May 1 [Updated 2016 Jul 1]. In: Markossian S, Sittampalam GS, Grossman A, et al., editors. Assay Guidance Manual [serial on the internet]. Bethesda (MD): Eli Lilly \& Company and the National Center for Advancing Translational Sciences; 2004 [cited 2020 Nov 11]. Available from: https://www.ncbi.nlm.nih.gov/books/ NBK144065/.

24. Lopez-Garcia J, Lehocky M, Humpolicek P, Saha P. HaCaT keratinocytes response on antimicrobial atelocollagen substrates extent of cytotoxicity, cell viability and proliferation. J Funct Biomater. 2014; 5(2):43-57.

25. Ricciotti E, FirzGerald GA. Prostaglandins and inflammation. Arterioscler Thromb Vasc Biol. 2011;31(5):986-1000.

26. Filip B. Inhibition of mPGES-1 as therapeutic strategy in inflammation and cancer $[\mathrm{PhD}$ thesis]. Boston: Karolinska Institutet, 2019.

27. Silva L, Neto APS, Maia SMAS, Guimaraes CDS, Quidute IL, Carvalho ADAT, et al. The role of TNF- $\alpha$ as pro-inflammatory cytokine in pathological processes. Open
Dent J. 2019;13:332-8.

28. Abdul Kadir NA, Rahmat A, Jaafar HZ. Protectuve effects if tamarillo (Cyphomandra betacea) extract against high fat diet induced obesity in Sprague-Dawley Rats. J Obes. 2015;2015:84601.

29. Rahmawati P, Sutanto, Miranti, M. Identifikasi senyawa antioksidan ekstrak etanol kulit terong belanda (Cyphomandra betacea Cav) Miers.) secara liquid chromategraphymass spectroscopy (LC-MS) [homepage on the internet]. Nodate [cited 2020 Nov 11]. Available from: http://www.perpustakaan.Fmipa.unpak. ac.id/file/ejurnal\% 20066111067.docx

30. Serrano A, Ros G, Nieto G. Bioactive compounds and extracts from traditional herbs and their potential anti-inflammatory health effects. Medicines. 2018;5(3):76.

31. Rathee P, Chaudhary H, Rathee S, Rathee D, Kumar V, Kohli K. Mechanism of action of flavonoids as anti-inflammatory agents: a review. Inflamm Allergy Drug Targets. 2009;8(3):229-35.

32. Kim HP, Son KH, Chang HW, Kang SS. AntiInflammatory plant flavonoids and cellular action mechanisms. J Pharmacol Sci. 2008;96(3):229-45.

33. Nijveldt RJ, Nood EV, Hoorn DEV, Boelens PG, Norren KV, Leeuwen PAV. Flavonoids: a review of probable mechanisms of action and potential applications. Am J Clin Nutr. 2001;74(4):418-25.

34. Mohammed MS, Osma WJA, Garelnabi EAE, Osman Z, Osman B, Khalid HS, et al. Secondary metabolites as anti-inflammatory agents. J Phytoph. 2014;3(4):275-85.

35. Viladomiu M, Hontecillas R, Lu P, BassaganyaRiera J. Preventive and prophylactic mechanisms of action of pomegranate bioactive constituents. Evid Based Complement Alternat Med. 2013;2013:789. 